\title{
Bioassay-Guided Isolation and Structure Elucidation of Bioactive Phytoconstituents with Inhibitory Activity against Carbohydrate-Hydrolyzing Enzymes from the Aerial Parts of Premna odorata Blanco
}

\author{
Ronel Abad Mendoza1, Chien-Chang Shen², Po-Wei Tsai ${ }^{3, *}$, Kathlia Aguila De Castro-Cruz ${ }^{1, *}$ \\ ${ }^{1}$ School of Chemical, Biological and Materials Engineering and Sciences, Mapúa University, Metro Manila, PHILIPPINES. \\ ${ }^{2}$ National Research Institute of Chinese Medicine, Ministry of Health and Welfare, Taipei, TAIWAN. \\ ${ }^{3}$ Department of Medical Sciences Industry, College of Health Sciences, Chang Jung Christian University, Tainan, TAIWAN.
}

\begin{abstract}
Background: This study aimed to isolate the bioactive components from the aerial parts of Premna odorata Blanco and to evaluate the hypoglycemic potentials of the crude extracts, sub-fractions and final isolate. Materials and Methods: The plant material underwent a series of enzyme assay-guided isolation and purification having the fractions assayed for inhibitory activity against $\alpha$-amylase using 3,5-dinitrosalicylic acid (DNS) colorimetric method for each stage. $\mathrm{H} .1$ isolate was tested for $\alpha$-amylase and $\alpha$-glucosidase inhibitory activity and glucose uptake by yeast cells. Phytochemical characterization and ${ }^{1} \mathrm{H}$ and ${ }^{13} \mathrm{C}$ NMR spectral analysis were done for the structure elucidation of H.1. Results: In vitro amylase studies revealed that at $100 \mu \mathrm{g} / \mathrm{mL}$ concentrations, hexane crude extract, fraction $\mathrm{F}(20 \% / 80 \%$ and $10 \% / 90 \%$ n-hexane/dichloromethane fractions) and $\mathrm{F} .3$ (10:1 $\mathrm{v} / \mathrm{v}$ petroleum ether/ethyl acetate sub-fraction) exhibited $34.38 \pm 0.116 \%, 71.86 \pm$ $4.909 \%$ and $42.16 \pm 1.257 \%$ inhibition against $\alpha$-amylase (at $1000 \mu \mathrm{g} / \mathrm{mL}$ concentration), respectively. H. 1 isolate exerted significant inhibition ( $p<0.05$ ) of $55.99 \pm 2.202 \%$ and $72.43 \pm 3.988 \%$ against $\alpha$-amylase and $\alpha$-glucosidase enzyme (both at $1000 \mu \mathrm{g} / \mathrm{mL}$ concentration), respectively and significant glucose uptake of $13.85 \pm 0.368 \%$. The purified isolate was spectroscopically confirmed as a $5: 1$ mixture of $\beta$ - sitosterol $(\mathrm{H} .1 \mathrm{a})$ and stigmasterol ( $\mathrm{H} .1 \mathrm{~b})$. Conclusion: The compounds have significant inhibitory activity against carbohydrate-hydrolyzing enzymes and may be potentially developed as adjuvant pharmacotherapy for type 2 diabetes.
\end{abstract}

Key words: Premna odorata, $\alpha$-amylase, $\alpha$-glucosidase, Bioassay, Hyperglycemia, Inhibition.

\section{INTRODUCTION}

In 2019, International Diabetes Federation statistically determined that roughly 463 million adults are affected by diabetes mellitus, well-known as diabetes. ${ }^{1}$ Sustained reduction in postprandial hyperglycemia will lower the risk of developing cardiovascular diseases, bone and joints disorders, cerebrovascular and peripheral vascular diseases and other long-term complications including skin-related problems, sexual dysfunction and digestive and metabolism problems. ${ }^{2}$ The emerging demands for therapeutic agents that can manage this metabolic disorder had led natural product experts to identify and isolate naturallyoccurring compounds having antidiabetic properties from plants. ${ }^{3}$ Prior to the discovery of insulin by Banting and Best (1922), the primary diagnosis of diabetes is solely based on traditional practices. ${ }^{4}$ Most common families of medicinal plants both ethno-botanically known and scientifically identified to have anti-hyperglycemic property are Asteraceae, Euphorbiaceae and Gentianaecae. $^{5}$
Submission Date: 12-09-2020; Revision Date: 07-02-2021; Accepted Date: 07-06-2021

DOI: 10.5530/ijper.55.3.158 Correspondence: Dr. Po-Wei Tsai

Department of Medical Sciences Industry, College of Health Sciences, Chang Jung Christian University,

Tainan-711, TAIWAN.

Phone: 886-06-2785123

Email id: powei@mail.cjcu. edu.tw

Dr. Kathlia A. De

Castro-Cruz

School of Chemical,

Biological and Materials

Engineering and

Sciences, Mapúa

University, Metro Manila, PHILIPPINES.

Phone: +63-2-82475000 Email id:

kadecastro@mapua.edu. ph

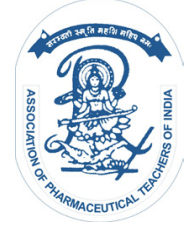

www.ijper.org 
Oral hypoglycemic agents known for treatment and management of type 2 diabetes are metformin, acarbose, sulfonylureas and meglitinides or glinides (insulin secretagogues), thiazolidinediones, dipeptidyl peptidase-4 inhibitors, such as sitagliptin, vildagliptin, saxagliptin, linagliptin and alogliptin and sodium glucose co-transporter-2 inhibitors like dapagliflozin, canagliflozin and empagliflozin. ${ }^{6-11}$ However, each oral agent has its own pharmacokinetics, effectiveness and pleiotropic, cardiovascular and other side effects. ${ }^{12}$ World ethnobotanical information has reported that almost 800 plants have potential hypoglycemic property. ${ }^{13}$ Ampalaya fruit (Momordica charantia), garlic (Allium sativum L.) and turmeric or luyang dilaw (Curcuma longa), kangkong leaves (Ipomoea aquatica), malunggay leaves (Moringa oleifera) and banaba leaves (Lagerstroemia speciose) are some plants in the Philippines that underwent preliminary studies for their anti-hyperglycemic properties. ${ }^{14-18}$ World Health Organization (WHO) has statistically determined that about $80 \%$ of the world's population still prefer phytomedicine or herbal medicine for primary healthcare over conventional therapies due to unexpected or dissatisfied outcomes, expensive cost of treatments and severe side effects of oral agents. ${ }^{19}$ The primary reason of diabetes is oxidative stress and growing presence of reactive oxygen species. ${ }^{20}$ Plants are natural antioxidants that prevent beta-cell dysfunction, increase the performance of pancreatic cell for better insulin secretion or reducing intestinal absorption of glucose and maintain blood glucose level. ${ }^{21}$ In particular, these plants are abundant in antidiabetic compounds such as flavonoids, tannins, phenolic and alkaloids. ${ }^{22}$ Moreover, some $25 \%$ of the prescription drugs are still derived either directly or indirectly from plants. ${ }^{23}$ With these supporting information, it is requisite for researchers and scientists to continuously study naturally-occurring compounds for possible treatments of various diseases such as diabetes.

Premna odorata Blanco, widely known as "alagaw/ alagau", is a tree native to tropical Asia, including the Philippines and is used as a traditional medicine by indigenous groups and local residents. ${ }^{24,25} \mathrm{It}$ is one of the blends of the commercialized herbal mixture known as "Pito-Pito", which is used for folkloric applications of headaches, abdominal pains, fever, cough, colds, migraine, asthma and diarrhea. ${ }^{26}$ The decoction of alagaw leaves was reported to have medicinal properties for respiratory disorders and calmative properties for nervous conditions like palpitations. ${ }^{27}$ Other significant medicinal properties of $P$. odorata are cytotoxic activity against HL-60 and MCF-7 cancer cell lines, anti-viral and anti-microbial activity. ${ }^{28-31}$ However, there are still no existing research claiming the plant as a possible source of hypoglycemic agents. Hence, the present study was undertaken to isolate the inhibitory components against $\alpha$-glucosidase and $\alpha$-amylase from the aerial part (leaves, stem, fruit and flower) of P. odorata. The isolated compound was also studied for their effects on glucose transport across yeast cells. Only fraction containing the highest activity of the $\alpha$-amylase inhibitors underwent further purification and the final isolate was subjected to ${ }^{1} \mathrm{H}$ and ${ }^{13} \mathrm{C}$ NMR spectroscopic analyses for structure elucidation.

\section{MATERIALS AND METHODS}

\section{Plant Materials and Identification}

The aerial parts (leaves, stem, flower and fruits) of $P$. odorata were collected from San Fernando, Pampanga, Philippines on March 2016. The plant was also taxonomically identified and certified by Manuel D. Ching, Chief (CIPGR Section) of the Bureau of Plant Industry which was filed at Mapúa University. The aerial parts of the plant were washed, air dried for one week and grinded using a blender. The total mass of the grinded aerial parts of the plant materials was $5 \mathrm{~kg}$.

\section{In vitro Pancreatic Amylase Inhibition Assay}

The amylase inhibitory activity assay was conducted according to the procedure performed by Kazeem et al. with trivial alterations. ${ }^{32}$ Briefly, the plant extract solution was prepared by mixing approximately $0.01 \mathrm{~g}$ of each of the chosen fractions with $100 \mathrm{~mL}$ of $0.02 \mathrm{M}$ phosphatebuffered saline (PBS, $6.7 \mathrm{mM} \mathrm{NaCl}, \mathrm{pH}$ of 6.9 ) or with DMSO for nonpolar extracts. All the solutions were subjected to a sonicator without heat for a duration of two hours. Then, the solutions were filtered for the removal of undissolved solid residues. Afterwards, 100 $\mu \mathrm{L}$ of refrigerated $\alpha$-amylase enzyme solution (0.005 $\mathrm{g}$ in $5 \mathrm{~mL} 0.02 \mathrm{M} \mathrm{PBS}$ ) was added to $100 \mu \mathrm{L}$ plant extract solution. Following this, the reaction mixtures were incubated for roughly $10 \mathrm{~min}$ at $25^{\circ} \mathrm{C}$. After preincubation, $100 \mu \mathrm{L}$ of a $1 \%(\mathrm{w} / \mathrm{v})$ starch solution was added with the sample mixtures. The samples were incubated furthermore for $10 \mathrm{~min}$ at $25^{\circ} \mathrm{C}$. The addition of $200 \mu \mathrm{L}$ of dinitrosalicylic acid solution (DNS, 30 g sodium potassium tartrate tetrahydrate, $20 \mathrm{~mL} 2 \mathrm{M}$ $\mathrm{NaOH}, 1 \mathrm{~g}$ DNS powder and $100 \mathrm{~mL}$ distilled water) was done to stop the enzymatic reaction. The solutions were heated for $15 \mathrm{~min}$ in a boiling water bath. Afterwards, the solutions were cooled. Following this, the solutions were diluted with $3 \mathrm{~mL}$ cold distilled water. For each concentration of the extract used, blank solutions were prepared by replacing amylase solution with $100 \mu \mathrm{L}$ PBS. 
This was done to deduct the absorbance generated by the plant extract from the overall absorbance. Negative control incubations, representing 100\% amylase activity, was established by doing the same procedure but replacing the plant extract with $100 \mu \mathrm{L}$ PBS. Likewise, another blank was prepared for pure control having $0 \%$ enzyme activity. Acarbose solution (100 ppm) was used as the positive control and treated in the same manner as the plant extract solution. All assay procedures were performed in triplicate. The absorbance of the yelloworange resulting solution was measured using UV-visible spectrophotometer at $540 \mathrm{~nm}$.

The results were demonstrated using percent inhibition. $\%$ Inhibition $=\frac{(\mathrm{Ac}+-\mathrm{Ac}-)-(\mathrm{As}-\mathrm{Ab})}{A \mathrm{c}+-\mathrm{Ac}^{-}} \times 100 \%(1)$ where $\mathrm{Ac}+$ denotes the absorbance of $100 \%$ amylase activity of pure control, Ac- denotes the absorbance of blank for pure control having $0 \%$ amylase activity, As denotes the absorbance of test sample and $\mathrm{Ab}$ denotes the background absorbance of plant extract solution.

\section{In vitro $\mathrm{\square -Glucosidase} \mathrm{Inhibition} \mathrm{Assay}$}

The glucosidase inhibitory activity assay was carried out according to the method performed by Bachhawat et al. with trivial alterations. ${ }^{33}$ Briefly, the plant extract solution was prepared by mixing approximately $0.01 \mathrm{~g}$ of each of the chosen fractions with $100 \mathrm{~mL}$ of 0.02 $\mathrm{M}$ phosphate-buffered saline (PBS, $50 \mathrm{mM} \mathrm{NaCl}, \mathrm{pH}$ of 6.9) or with DMSO for nonpolar extracts. All the solutions were subjected to a sonicator without heat for a duration of two hours. Then, the solutions were filtered for the removal of undissolved solid residues. Afterwards, $50 \mu \mathrm{L}$ of refrigerated $\alpha$-glucosidase enzyme solution $(0.0033 \mathrm{~g}$ in $3.3 \mathrm{~mL}$ of $0.1 \mathrm{M}$ PBS) was added to $50 \mu \mathrm{L}$ plant extract solution. Following this, the reaction mixtures were incubated for roughly $10 \mathrm{~min}$ at $37^{\circ} \mathrm{C}$. After pre-incubation, $50 \mu \mathrm{L}$ of $5 \mathrm{mM}$ p-nitrophenyl- $\alpha$ D-glucopyranoside was added to the resulting mixture. Furthermore, the samples were incubated for $30 \mathrm{~min}$ at $37^{\circ} \mathrm{C}$. The addition of $50 \mu \mathrm{L}$ of $50 \mathrm{mM} \mathrm{NaOH}$ solution was done to stop the enzymatic reaction. Following this, the solutions were diluted with $3 \mathrm{~mL}$ cold distilled water. For each concentration of the extract used, blank solutions were prepared by replacing glucosidase solution with $100 \mu \mathrm{L}$ PBS. This was done to deduct the absorbance generated by the plant extract from the overall absorbance. Negative control incubations, representing $100 \%$ glucosidase activity, was established by doing the same procedure but replacing the plant extract with 100 $\mu \mathrm{L}$ PBS. Likewise, another blank was prepared for pure control having $0 \%$ enzyme activity. Acarbose solution $(100 \mathrm{ppm})$ was used as the positive control and treated in the same manner as the plant extract solution. All assay procedures were performed in triplicate. The absorbance of the yellow resulting solution was measured using UV-visible spectrophotometer at $405 \mathrm{~nm}$. The results were demonstrated using percent inhibition as shown by Equation 2.

$\%$ Inhibition $=\frac{(A c+-A c-)-(A s-A b)}{A c+-A c-} \times 100 \%$

where Ac+ denotes the absorbance of $100 \%$ glucosidase activity of pure control, Ac- denotes the absorbance of blank for pure control having $0 \%$ glucosidase activity, As denotes the absorbance of test sample and $\mathrm{Ab}$ denotes the background absorbance of plant extract solution.

\section{Glucose Uptake in Yeast Cells}

The principle of glucose uptake in yeast cells was based on the method carried out by Cirillo. ${ }^{34}$ Initially, commercial baker's yeast prepared in aqueous mixture underwent multiple stages of washing through centrifugation. The centrifuged yeast was obtained and a $10 \% \mathrm{v} / \mathrm{v}$ suspension was made in distilled water. Extract solution $(500 \mu \mathrm{g} / \mathrm{mL}$ ) was mixed with $25 \mathrm{mM}$ glucose solution. The resulting mixture was incubated for $10 \mathrm{~min}$ at $37^{\circ} \mathrm{C}$. The reaction was started by the addition of $100 \mu \mathrm{L}$ of yeast suspension. The mixture was incubated again for $60 \mathrm{~min}$ at $37^{\circ} \mathrm{C}$. Then, the mixture was centrifuged and the resulting supernatant underwent DNS colorimetric method to spectroscopically determine the remaining glucose. Metformin solution was used as the positive control and treated in the same manner as the plant extract solution. The absorbance of the yellow-orange resulting solution was measured using UV-visible spectrophotometer at $540 \mathrm{~nm}$.

The percent increase in glucose uptake by yeast cells was estimated using the formula below.

Increase in glucose uptake $(\%)=\frac{\mathrm{Abs}_{\text {control }}-\mathrm{Abs}_{\text {sammle }}}{\mathrm{Abs}} \times 100 \%$ (3)

where $\mathrm{Abs}_{\text {control }}$ denotes the absorbance of the control (comprising all the reagents except the test sample) and $\mathrm{Abs}_{\text {sample }}$ denotes the absorbance of the test sample (plant extract and metformin).

\section{Bioassay-Guided Isolation and Purification of the Plant Material}

Five 30-g samples of the plant were soaked in each of the following solvents: water, acetone, dichloromethane (DCM) or methylene chloride and $n$-hexane. The soaking lasted for three days. Afterwards, the extractcontaining solvents were air-dried. The crude extracts obtained from each soaking solvent were evaluated for their enzymatic inhibition activity against $\alpha$-amylase. Finally, the extract which exhibited the highest inhibition 
activity was chosen for gradient elution chromatography. The remaining grinded sample of $P$. odorata was soaked in the chosen solvent for three days. Then, the extracts were filtered and air-dried. The chosen extract, with $5 \mathrm{~mL}$ volume, was subjected to gradient elution chromatography having 10\% increment, starting from the least polar up to the most polar mobile phase. Thinlayer chromatography was performed for the monitoring of the separation process of the different fractions obtained. Fractions with the same retention factor were combined and subjected to $\alpha$-amylase assay. Further purification was done for the fraction obtained from the gradient elution chromatography having the highest percent inhibition against the enzyme. The purification process involved flash liquid column chromatography with thin layer chromatogram monitoring. Eluents from the different fractions having the same retention factor were combined and tested for inhibition activity against the enzyme. The purified fraction was purified again using petroleum ether for the removal of residues and pigments. The purified fractions were stored in the refrigerator for structure elucidation.

\section{Phytochemical Characterization and Structure Elucidation}

The purified isolate, H.1, was subjected to nuclear magnetic resonance (Varian VNMRS Spectrometer in $\mathrm{CDCl}_{3}$ at $600 \mathrm{MHz}$ ) for structure elucidation of the active constituents from the aerial parts of P. odorata. Salkowski test was performed to detect any presence of sterol in the final isolate. The procedure involved shaking equal volumes of chloroform and extract dissolved in DMSO. Afterwards, equal volume of concentrated sulfuric acid was slowly added. If sterol is present in sufficient amount, the chloroform layer (upper layer) assumes a cherry-red to purple color while the sulfuric acid layer (lower layer) is seen to be brownish-yellow that becomes deeper and redder for several hours. ${ }^{35}$

\section{Statistical Analysis}

Experimental data were collected in triplicate and expressed as mean \pm SEM (standard error of mean). Levene's test of homogeneity of variances was performed. The test assumes equal variances if $p>$ 0.05. Significance of differences among the groups was analyzed by performing one-way analysis of variance (ANOVA), followed by Dunnett's post hoc test for comparison of the test samples to the control group. The software used to perform these tests was IBM SPSS Statistics 25. The differences were deemed significant at $p<0.05$.

\section{RESULTS AND DISCUSSION}

One of the therapeutic approaches to pharmacology of type 2 diabetes is targeting enzymes known to hydrolyze complex carbohydrates prompting an elevated level of postprandial plasma glucose. Pancreatic $\alpha$-amylase inhibition has been one of the targets for glycemic control by preventing or delaying the oligosaccharide breakdown to absorbable simple sugars in the intestinal brush border, prompting a lowered blood glucose level and subsequently postprandial insulin release. ${ }^{36}$ Moreover, another therapeutic target involves $\alpha$-glucosidase suppression to delay starch and glycogen breakdown into their monomers. ${ }^{37}$ Non-insulin dependent glucose uptake has also been a therapeutic alternative for type 2 diabetes treatment. ${ }^{38}$ Hence, the extract of $P$. odorata underwent in vitro $\alpha$-amylase inhibitory studies through DNS colorimetric method, $\alpha$-glucosidase inhibitory assay and glucose uptake by yeast cells. The isolation of the possible hypoglycemic agent involved a series of enzyme assay-guided separation, as depicted in Figure 1 . The inhibitory activities of the crude extracts from various soaking solvents were determined for the selection of solvent, as shown in Figure 2 (a). Hexane crude extract exhibited the maximal inhibition activity against $\alpha$-amylase with $34.38 \pm 0.116 \%$ inhibition. The standard positive control acarbose showed 68.79 \pm $0.112 \%$ inhibition against $\alpha$-amylase. There was a statistically significant difference $(p<0.05)$ among the inhibitory activities of the extracts and the positive control. However, post hoc tests determined that the crude extracts of acetone, $n$-hexane and standard drug, acarbose had significant differences when compared with the negative control while the crude extracts of

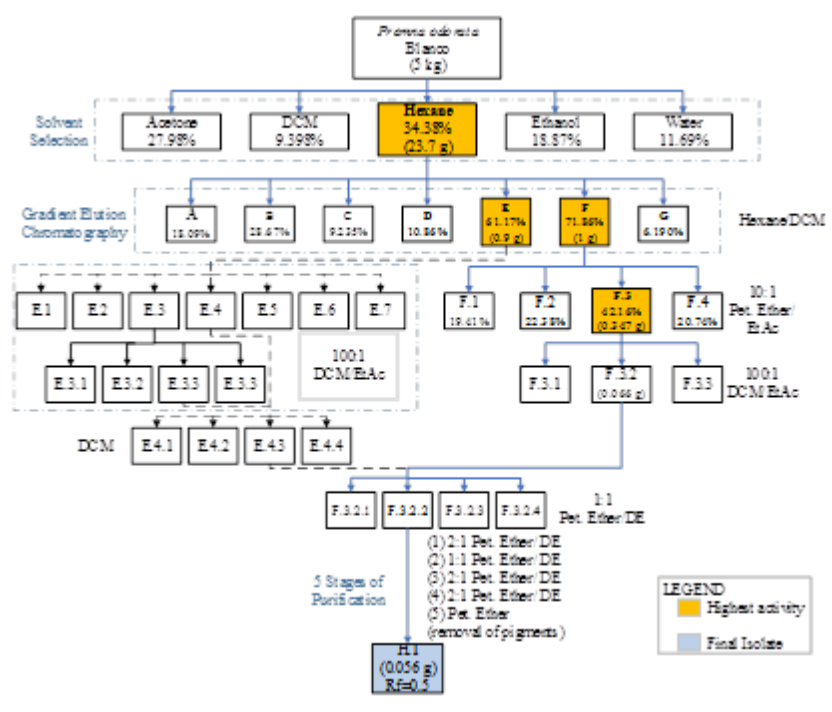

Figure 1: Bioassay-guided isolation of active components having inhibitory activity against $\square$-amylase. 
water, dichloromethane and ethanol had insignificant differences. The remaining dried powders of $P$. odorata were soaked in $n$-hexane. The total mass of the hexane crude extract was $23.718 \mathrm{~g}$.

Thin layer chromatography showed a good separation on the extract when 1:1 $n$-hexane/dichloromethane solvent system was used as a mobile phase. Different fractions were obtained for every 10\% increment of the solvent, starting from the least polar ( $n$-hexane) up to the most polar (dichloromethane) solvent. The fractions containing the same retention factor, as visualized on the TLC plate, were combined. A total of 7 fractions were obtained after the gradient elution chromatography. The inhibitory activities of each fraction were determined and are shown in Figure 2 (b). Fraction F (20\%/80\% and 10\%/90\% $n$-hexane/dichloromethane) exhibited the maximal inhibition activity against $\alpha$-amylase with $71.86 \pm 4.909 \%$ inhibition. The aforementioned fraction exceeded the activity of the standard positive control acarbose that showed $70.56 \pm 3.249 \%$ inhibition against $\alpha$-amylase. There was a statistically significant difference $(p<0.05)$ among the inhibitory activities of the extracts and the positive control. However, post hoc tests determined that Fraction E, Fraction $\mathrm{F}$ and acarbose had significant differences when compared with the negative control while Fraction A, B, C, D and G had insignificant differences. Approximately $1 \mathrm{~g}$ of Fraction $F$ was collected after gradient elution chromatography. F.1 (0.1958 g), F.2 (0.0842 g), F.3 (0.3468 g) and F.4 $(0.0727 \mathrm{~g})$ were obtained after subjecting Fraction F to flash column chromatography using 10:1 petroleum ether/ethyl acetate as mobile phase. The inhibitory activities of each fraction were determined and are shown in Figure 2 (c). From all the fractions obtained, F.3 exhibited the maximal inhibition activity against $\alpha$-amylase with $42.16 \pm 1.257 \%$ inhibition. The aforementioned fraction failed to exceed the activity of the standard positive control acarbose that showed $73.77 \pm 2.101 \%$ inhibition against $\alpha$-amylase. There was a statistically significant difference $(p<0.05)$ among the inhibitory activities of the extracts and the positive control. Post hoc tests determined that all fractions and acarbose had significant differences when compared with the negative control. ANOVA analysis showed that the fractions having the highest activities ( $n$-hexane, $\mathrm{F}$ and F.3) from each stage of fractionation are statistically different $(p<0.05)$.

The inhibitory activity of H.1 isolate against $\alpha$-amylase was determined and is shown in Figure 3 (a). The final isolated extract exhibited $55.99 \pm 2.202 \%$ inhibition against $\alpha$-amylase. The aforementioned fraction failed to exceed the activity of the standard positive control
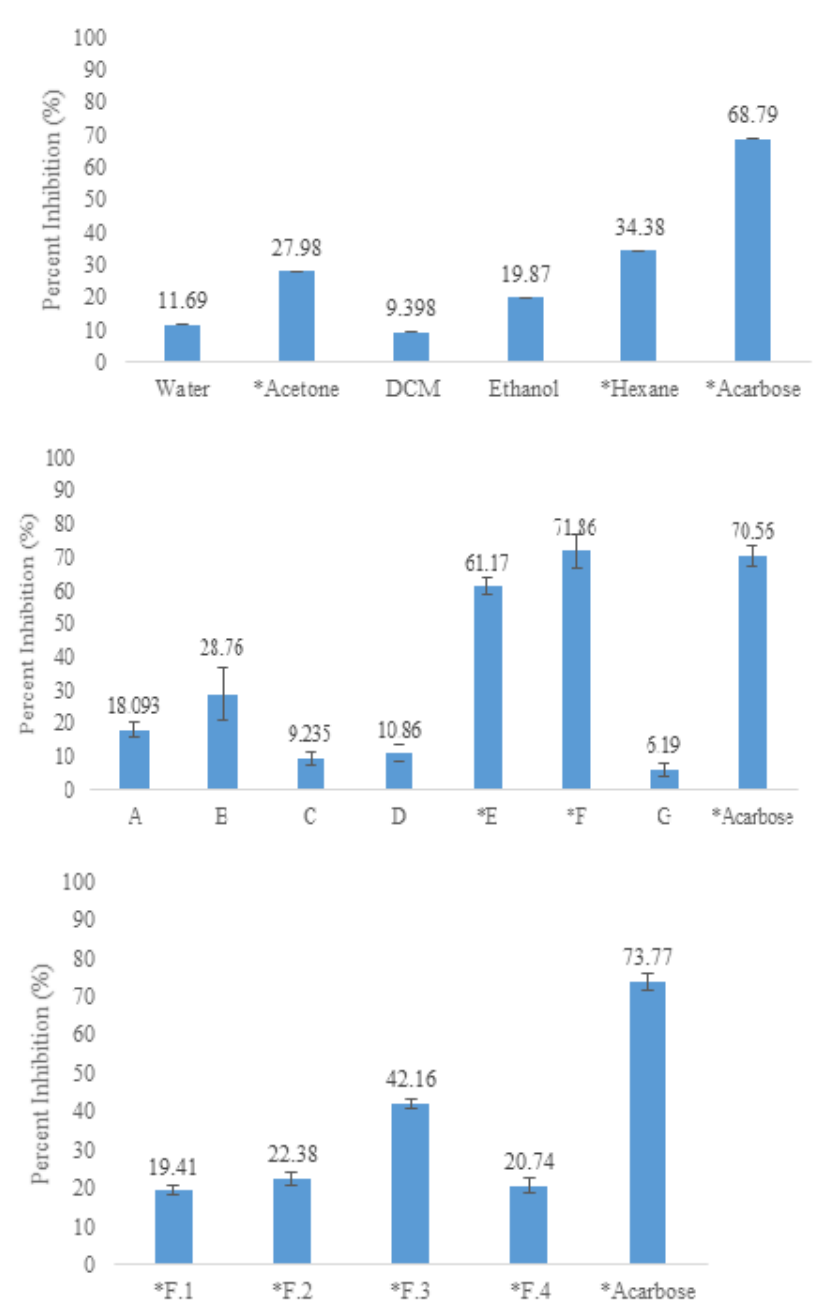

Figure 2: - -Amylase percent inhibition of fractions (a) from various soaking solvents, (b) from gradient elution chromatography and (c) from purification. The data are indicated as the mean \pm SEM; $(n=3)$. Asterisks $\left({ }^{*}\right)$ were assigned to samples that showed significant difference with respect to control $(p<0.05)$. Positive Control: Acarbose.

acarbose that showed $68.35 \pm 1.917 \%$ inhibition against $\alpha$-amylase. There was a statistically significant difference $(p<0.05)$ among the inhibitory activities of the isolate and the positive control. Post hoc tests determined that H.1 isolate and acarbose had a significant difference when compared with the negative control.

The H.1 isolate and acarbose were able to demonstrate some inhibitory activity against $\alpha$-glucosidase enzyme, as shown in Figure 3 (b). H.1 isolate, having 72.43 $\pm 3.988 \%$ inhibition against $\alpha$-glucosidase, exceeded the inhibitory activity exhibited by the standard drug acarbose that showed $50.21 \pm 4.571 \%$ inhibition. There was a statistically significant difference $(p<0.05)$ among the inhibitory activities of the isolate and the positive control. Post hoc tests determined that H.1 isolate and 
acarbose had a significant difference when compared with the negative control.

The research was able to assess the in vitro antidiabetic potential of H.1 isolate and metformin using glucose uptake by yeast cells, as shown in Figure 3 (c). H.1 isolate, having $13.85 \pm 0.368 \%$ uptake failed to exceed the glucose uptake exhibited by the standard drug metformin that showed $50.81 \pm 0.660 \%$ uptake. There was a statistically significant difference $(p<0.05)$ between the uptake of the isolate and the positive control. Post hoc tests determined that H.1 isolate and metformin had a significant difference when compared with the negative control.

H.1 isolate $(0.0557 \mathrm{~g})$ was isolated as a white amorphous and needle-like powder with a characteristic odor that is soluble in non-polar solvents like dichloromethane, $n$-hexane and petroleum ether and insoluble in polar solvents like water. It produced a positive result for sterol when Salkowski test was performed. There was a formation of purple color in the chloroform layer (upper layer) and yellow-brown in the sulfuric layer (lower layer) which demonstrates the presence of sterol. The $\mathrm{R}_{f}$ value of the purified isolate was 0.50 using 1:1 petroleum ether/diethyl ether solvent system.

${ }^{1} \mathrm{H}$ NMR spectra displayed three olefinic protons at $\delta 5.000$ (dd), 5.100-5.150 (dd) and 5.333 (br. s.) ppm. The multiplet at $\delta 3.522 \mathrm{ppm}$ is attributed to the carbon attached to the $\mathrm{OH}$ group. The three methyl doublets that appeared at $\delta 0.810,0.813$ and $0.989 \mathrm{ppm}$, two methyl singlets at $\delta 0.678$ and $0.996 \mathrm{ppm}$ and a methyl triplet at $\delta 0.826 \mathrm{ppm}$ were revealed by ${ }^{1} \mathrm{H}$ NMR spectra. Complex multiplets at $\delta 2.235,2.283,1.491$ and 1.834 ppm corresponded to the two $\mathrm{CH}_{2}$ adjacent to the carbon attached to the $\mathrm{OH}$ group.

Distinct ${ }^{13} \mathrm{C}$ NMR signals at $\delta 140.759$ and $121.718 \mathrm{ppm}$ corresponded to tri-substituted double bonds, C5=C6. Substituted alkene, $\mathrm{C} 22=\mathrm{C} 23$, was also revealed by the $\delta 138.310$ and 129.275 ppm signals. Moreover, $\mathrm{CH}(\mathrm{OH})$ bond was also identified by the $\delta 71.812 \mathrm{ppm}$ signal.

Salkowski test result highly suggested that H.1 has a sterol backbone. The distinct signals displayed by ${ }^{1} \mathrm{H}$ NMR and ${ }^{13} \mathrm{C}$ NMR spectra propose that $\mathrm{H} .1$ isolate is a stigmasterol. However, ${ }^{13} \mathrm{C}$ NMR spectra demonstrated almost 40 carbon signals but stigmasterol only has 29 carbons. This means that H.1 is a combination of compounds. The NMR signals resembled the signals of $\beta$-sitosterol and stigmasterol based on literature, as depicted in Tables 1 and 2. Moreover, $\beta$-sitosterol and stigmasterol have been previously identified from the hexane extract and DCM sub-extract of the leaves of $P$. odorata. ${ }^{39,40}$ The structures of the isolated compounds are shown in Figure 4.
The study was able to demonstrate the antidiabetic effect of $P$. odorata by testing its inhibitory activity against carbohydrate-hydrolyzing enzymes and glucose uptake by yeast cells. The purified isolate underwent in vitro bioassays for its amylase and glucosidase enzyme inhibition and glucose uptake by yeast cells. Acarbose was used as the positive control for both enzyme inhibition assay while metformin was utilized for glucose uptake by yeast cells. The purified isolate, H.1, was able to exhibit significant $\alpha$-amylase and $\alpha$-glucosidase inhibitory activity. It was revealed that the effectiveness of the purified isolate as $\alpha$-glucosidase inhibitor was greater than that of the positive control. Additionally, significant glucose uptake was observed for the purified isolate. It can be scrutinized that the percent inhibition against $\alpha$-amylase varies from every stage of isolation. The variation of the activity from every stage can be caused by the synergistic activity of phytoconstituents in combination with possible hypoglycemic agents present in the extract.

In vitro enzyme inhibition study of Kumar et al. has revealed that $\beta$-sitosterol and stigmasterol showed 48.8 and $44.3 \% \alpha$-amylase inhibition, respectively and 52.5 and $34.2 \% \alpha$-glucosidase inhibition, respectively, at the dose of $50 \mu \mathrm{g} / \mathrm{kg}^{45}$ A 21 -day $\beta$-sitosterol treatment

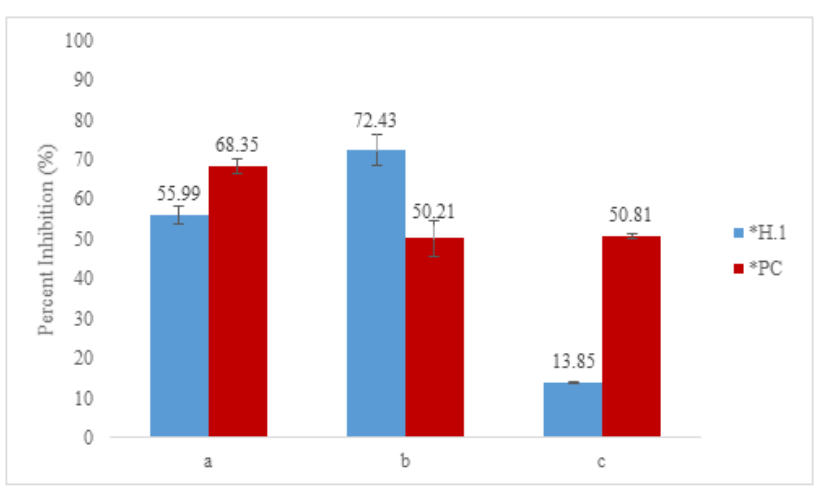

Figure 3: (a) प-Amylase percent inhibition, (b) प-glucosidase percent inhibition and (c) glucose uptake by yeast cells. The data are indicated as the mean \pm SEM; $(n=3)$. Asterisks $\left(^{*}\right)$ were assigned to samples that showed significant difference with respect to control $(p<0.05)$. Positive Control (PC): Acarbose (a and b), Metformin (c).

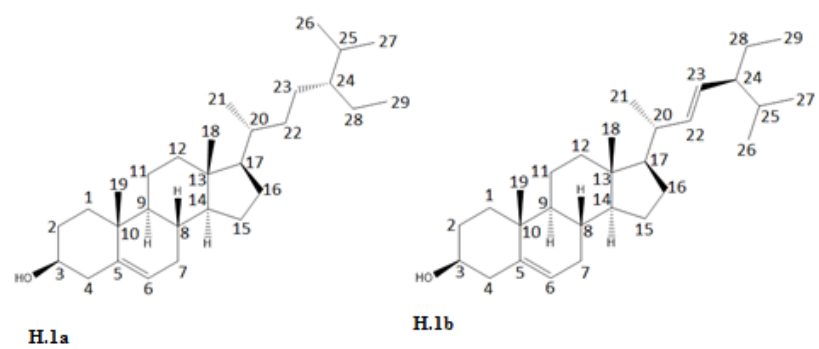

Figure 4: ૧-Sitosterol (H.1a) and Stigmasterol (H.1b). 


\begin{tabular}{|c|c|c|c|c|}
\hline Carbon & H.1a & $\beta$-Sitosterol ${ }^{41}$ & H.1b & Stigmasterol ${ }^{41,42}$ \\
\hline Position & $\delta_{H}$ & $\delta_{H}$ & $\delta_{H}$ & $\delta_{H}$ \\
\hline 1 & $\begin{array}{l}1.084(1 \mathrm{H}, \mathrm{m}) \\
1.839(1 \mathrm{H}, \mathrm{m})\end{array}$ & $\begin{array}{l}1.08(1 \mathrm{H}, \mathrm{m}) \\
1.83(1 \mathrm{H}, \mathrm{m})\end{array}$ & $\begin{array}{l}1.084(1 \mathrm{H}, \mathrm{m}) \\
1.839(1 \mathrm{H}, \mathrm{m})\end{array}$ & $\begin{array}{l}1.08(1 \mathrm{H}, \mathrm{m}) \\
1.83(1 \mathrm{H}, \mathrm{m})\end{array}$ \\
\hline 2 & $\begin{array}{l}1.491(1 \mathrm{H}, \mathrm{m}) \\
1.834(1 \mathrm{H}, \mathrm{m})\end{array}$ & $\begin{array}{l}1.49(1 \mathrm{H}, \mathrm{m}) \\
1.82(1 \mathrm{H}, \mathrm{m})\end{array}$ & $\begin{array}{l}1.491(1 \mathrm{H}, \mathrm{m}) \\
1.834(1 \mathrm{H}, \mathrm{m})\end{array}$ & $\begin{array}{l}1.49(1 \mathrm{H}, \mathrm{m}) \\
1.82(1 \mathrm{H}, \mathrm{m})\end{array}$ \\
\hline 3 & $3.522(1 \mathrm{H}, \mathrm{m})$ & $3.53(1 \mathrm{H}, \mathrm{m})$ & $3.522(1 \mathrm{H}, \mathrm{m})$ & $3.53(1 \mathrm{H}, \mathrm{m})$ \\
\hline 4 & $\begin{array}{l}2.235(1 \mathrm{H}, \mathrm{m}) \\
2.283(1 \mathrm{H}, \mathrm{m})\end{array}$ & $\begin{array}{r}2.24(1 \mathrm{H}, \mathrm{m}) \\
2.28(1 \mathrm{H}, \mathrm{m})\end{array}$ & $\begin{array}{l}2.235(1 \mathrm{H}, \mathrm{m}) \\
2.283(1 \mathrm{H}, \mathrm{m})\end{array}$ & $\begin{array}{r}2.24(1 \mathrm{H}, \mathrm{m}) \\
2.28(1 \mathrm{H}, \mathrm{m})\end{array}$ \\
\hline 5 & - & - & - & - \\
\hline 6 & 5.333 (br. s.) & 5.35 (br. s.) & 5.333 (br. s.) & 5.35 (br. s.) \\
\hline 7 & $\begin{array}{c}1.567(1 \mathrm{H}, \mathrm{m}) \\
1.98(1 \mathrm{H}, \mathrm{m})\end{array}$ & $\begin{array}{c}1.56(1 \mathrm{H}, \mathrm{m}) \\
1.98(1 \mathrm{H}, \mathrm{m})\end{array}$ & $\begin{array}{c}1.534(1 \mathrm{H}, \mathrm{m}) \\
1.98(1 \mathrm{H}, \mathrm{m})\end{array}$ & $\begin{array}{l}1.53(1 \mathrm{H}, \mathrm{m}) \\
1.98(1 \mathrm{H}, \mathrm{m})\end{array}$ \\
\hline 8 & $1.466(1 \mathrm{H}, \mathrm{m})$ & $1.46(1 \mathrm{H}, \mathrm{m})$ & $1.466(1 \mathrm{H}, \mathrm{m})$ & $1.46(1 \mathrm{H}, \mathrm{m})$ \\
\hline 9 & $0.933(1 \mathrm{H}, \mathrm{m})$ & $0.94(1 \mathrm{H}, \mathrm{m})$ & $0.933(1 \mathrm{H}, \mathrm{m})$ & $0.94(1 \mathrm{H}, \mathrm{m})$ \\
\hline 10 & - & - & - & - \\
\hline 11 & $\begin{array}{l}1.448(2 \mathrm{H}, \mathrm{m}) \\
1.479(2 \mathrm{H}, \mathrm{m})\end{array}$ & $\begin{array}{c}1.45(2 \mathrm{H}, \mathrm{m}) \\
1.48(2 \mathrm{H}, \mathrm{m})\end{array}$ & $\begin{array}{l}1.448(2 \mathrm{H}, \mathrm{m}) \\
1.479(2 \mathrm{H}, \mathrm{m})\end{array}$ & $\begin{array}{l}1.45(2 \mathrm{H}, \mathrm{m}) \\
1.48(2 \mathrm{H}, \mathrm{m})\end{array}$ \\
\hline 12 & $\begin{array}{l}1.165(1 \mathrm{H}, \mathrm{m}) \\
1.971(1 \mathrm{H}, \mathrm{m})\end{array}$ & $\begin{array}{l}1.15(1 \mathrm{H}, \mathrm{m}) \\
1.97(1 \mathrm{H}, \mathrm{m})\end{array}$ & $\begin{array}{l}1.165(1 \mathrm{H}, \mathrm{m}) \\
1.971(1 \mathrm{H}, \mathrm{m})\end{array}$ & $\begin{array}{l}1.15(1 \mathrm{H}, \mathrm{m}) \\
1.97(1 \mathrm{H}, \mathrm{m})\end{array}$ \\
\hline 13 & - & - & - & - \\
\hline 14 & $1.034(1 \mathrm{H}, \mathrm{m})$ & $1.03(1 \mathrm{H}, \mathrm{m})$ & $0.989(1 \mathrm{H}, \mathrm{m})$ & $1.00(1 \mathrm{H}, \mathrm{m})$ \\
\hline 15 & $\begin{array}{l}1.057(1 \mathrm{H}, \mathrm{m}) \\
1.567(1 \mathrm{H}, \mathrm{m})\end{array}$ & $\begin{array}{l}1.05(1 \mathrm{H}, \mathrm{m}) \\
1.55(1 \mathrm{H}, \mathrm{m})\end{array}$ & $\begin{array}{l}1.062(1 \mathrm{H}, \mathrm{m}) \\
1.567(1 \mathrm{H}, \mathrm{m})\end{array}$ & $\begin{array}{l}1.06(1 \mathrm{H}, \mathrm{m}) \\
1.55(1 \mathrm{H}, \mathrm{m})\end{array}$ \\
\hline 16 & $1.248(1 \mathrm{H}, \mathrm{m})$ & $1.24(1 \mathrm{H}, \mathrm{m})$ & $\begin{array}{l}1.273(1 \mathrm{H}, \mathrm{m}) \\
1.648(1 \mathrm{H}, \mathrm{m})\end{array}$ & $\begin{array}{l}1.27(1 \mathrm{H}, \mathrm{m}) \\
1.71(1 \mathrm{H}, \mathrm{m})\end{array}$ \\
\hline 17 & $1.129(1 \mathrm{H}, \mathrm{m})$ & $1.13(1 \mathrm{H}, \mathrm{m})$ & $1.129(1 \mathrm{H}, \mathrm{m})$ & $1.13(1 \mathrm{H}, \mathrm{m})$ \\
\hline 18 & $0.66(3 \mathrm{H}, \mathrm{s})$ & $0.68(3 \mathrm{H}, \mathrm{s})$ & $0.678(3 \mathrm{H}, \mathrm{s})$ & $0.70(3 \mathrm{H}, \mathrm{s})$ \\
\hline 19 & $0.996(3 \mathrm{H}, \mathrm{s})$ & $1.01(3 \mathrm{H}, \mathrm{s})$ & $0.996(3 \mathrm{H}, \mathrm{s})$ & $1.01(3 \mathrm{H}, \mathrm{s})$ \\
\hline 20 & $1.342(1 \mathrm{H}, \mathrm{m})$ & $1.36(1 \mathrm{H}, \mathrm{m})$ & $2.008(1 \mathrm{H}, \mathrm{m})$ & $2.04(1 \mathrm{H}, \mathrm{m})$ \\
\hline 21 & $0.989(3 \mathrm{H}, \mathrm{d})$ & $0.94(3 \mathrm{H}, \mathrm{d})$ & $0.989(3 \mathrm{H}, \mathrm{d})$ & $1.02(3 \mathrm{H}, \mathrm{d})$ \\
\hline 22 & $1.329(2 \mathrm{H}, \mathrm{m})$ & $1.32(2 \mathrm{H}, \mathrm{m})$ & $\begin{array}{c}5.100-5.150 \\
(1 \mathrm{H}, \mathrm{dd})\end{array}$ & $5.15(1 \mathrm{H}, \mathrm{dd})$ \\
\hline 23 & $1.155(2 \mathrm{H}, \mathrm{m})$ & $1.15(2 \mathrm{H}, \mathrm{m})$ & $5.000(1 \mathrm{H}, \mathrm{dd})$ & $5.02(1 \mathrm{H}, \mathrm{dd})$ \\
\hline 24 & $0.933(1 \mathrm{H}, \mathrm{m})$ & $0.93(1 \mathrm{H}, \mathrm{m})$ & $1.534(1 \mathrm{H}, \mathrm{m})$ & $1.53(1 \mathrm{H}, \mathrm{m})$ \\
\hline 25 & $1.648(1 \mathrm{H}, \mathrm{m})$ & $1.65(1 \mathrm{H}, \mathrm{m})$ & $1.440(1 \mathrm{H}, \mathrm{m})$ & $1.44(1 \mathrm{H}, \mathrm{m})$ \\
\hline 26 & $0.810(3 \mathrm{H}, \mathrm{d})$ & $0.82(3 \mathrm{H}, \mathrm{d})$ & $0.810(3 \mathrm{H}, \mathrm{d})$ & $0.84(3 \mathrm{H}, \mathrm{d})$ \\
\hline 27 & $0.813(3 \mathrm{H}, \mathrm{d})$ & $0.83(3 \mathrm{H}, \mathrm{d})$ & $0.813(3 \mathrm{H}, \mathrm{d})$ & $0.83(3 \mathrm{H}, \mathrm{d})$ \\
\hline 28 & $1.220(1 \mathrm{H}, \mathrm{m})$ & $1.22(1 \mathrm{H}, \mathrm{m})$ & $1.165(1 \mathrm{H}, \mathrm{m})$ & $1.15(1 \mathrm{H}, \mathrm{m})$ \\
\hline 29 & $0.826(3 \mathrm{H}, \mathrm{t})$ & $0.85(3 \mathrm{H}, \mathrm{t})$ & $0.826(3 \mathrm{H}, \mathrm{t})$ & $0.80(3 \mathrm{H}, \mathrm{t})$ \\
\hline
\end{tabular}

to streptozotocin-induced diabetic rats has resulted in decreases in glycated hemoglobin, blood glucose and nitric oxide, with accompanying elevated levels of serum insulin. ${ }^{46} \beta$-sitosterol has also exhibited insulin sensitivity promotion in rats fed with diet high in fat possibly by increasing nitric oxide levels. ${ }^{47}$ The activity between $\beta$-sitosterol and stigmasterol has been known to synergistically enhance the hypoglycemic effect of the two compounds. ${ }^{48}$ Stigmasterol can also be a potential therapeutic drug for type 2 diabetes mellitus probably by targeting GLUT4 glucose transporter and enhancing GLUT4 expression and translocation. ${ }^{49}$

Plants are capable of producing mixtures of sterols including $\beta$-sitosterol, stigmasterol, campesterol and cholesterol. ${ }^{50}$ These phytosterols interact with phospholipids for plasma membrane fluidity 


\begin{tabular}{|c|c|c|c|c|c|}
\hline Carbon & H.1a & $\beta$-sitosterol ${ }^{43}$ & H.1b & Stigmasterol ${ }^{44}$ & $\begin{array}{c}\text { Nature of } \\
\text { Carbon }\end{array}$ \\
\hline Position & $\delta_{c}$ & $\delta_{c}$ & $\delta_{c}$ & $\delta_{c}$ & \\
\hline 1 & 37.252 & 37.3 & 37.252 & 37.3 & $\mathrm{CH}_{2}$ \\
\hline 2 & 31.876 & 31.9 & 31.876 & 31.9 & $\mathrm{CH}_{2}$ \\
\hline 3 & 71.812 & 71.9 & 71.812 & 71.9 & $\mathrm{CH}(\mathrm{OH})$ \\
\hline 4 & 42.306 & 42.3 & 42.306 & 42.3 & $\mathrm{CH}_{2}$ \\
\hline 5 & 140.759 & 140.8 & 140.759 & 140.8 & $\mathrm{C}=\mathrm{CH}$ \\
\hline 6 & 121.718 & 121.8 & 121.718 & 121.8 & $=\mathrm{CH}$ \\
\hline 7 & 31.669 & 31.7 & 31.669 & 31.7 & $\mathrm{CH}_{2}$ \\
\hline 8 & 31.906 & 32.0 & 31.906 & 32.0 & $\mathrm{CH}$ \\
\hline 9 & 50.191 & 50.2 & 50.191 & 50.2 & $\mathrm{CH}$ \\
\hline 10 & 36.505 & 36.6 & 36.505 & 36.6 & $\mathrm{QC}^{\mathrm{a}}$ \\
\hline 11 & 21.081 & 21.2 & 21.081 & 21.2 & $\mathrm{CH}_{2}$ \\
\hline 12 & 39.773 & 39.8 & 39.773 & 39.8 & $\mathrm{CH}_{2}$ \\
\hline 13 & 42.321 & 42.4 & 42.321 & 42.4 & $\mathrm{QC}^{\mathrm{a}}$ \\
\hline 14 & 56.768 & 56.8 & 56.768 & 56.8 & $\mathrm{CH}$ \\
\hline 15 & 24.300 & 24.4 & 24.300 & 24.4 & $\mathrm{CH}_{2}$ \\
\hline 16 & 28.243 & 28.3 & 28.243 & 28.3 & $\mathrm{CH}_{2}$ \\
\hline 17 & 56.055 & 56.1 & 56.055 & 56.1 & $\mathrm{CH}$ \\
\hline 18 & 11.854 & 11.9 & 11.854 & 11.9 & $\mathrm{CH}_{3}$ \\
\hline 19 & 19.395 & 19.5 & 19.027 & 19.1 & $\mathrm{CH}_{3}$ \\
\hline 20 & 36.144 & 36.2 & 40.482 & 40.6 & $\mathrm{CH}$ \\
\hline 21 & 18.774 & 18.9 & 18.974 & 20.0 & $\mathrm{CH}_{3}$ \\
\hline 22 & 33.945 & 34.0 & 138.310 & 138.4 & $\mathrm{CH}_{2} / \mathrm{C}=\mathrm{CH}$ \\
\hline 23 & 26.074 & 26.2 & 129.275 & 129.2 & $\mathrm{CH}_{2} / \mathrm{C}=\mathrm{CH}$ \\
\hline 24 & 45.838 & 46.0 & 51.234 & 51.3 & $\mathrm{CH}$ \\
\hline 25 & 29.151 & 29.2 & 33.945 & 34.0 & $\mathrm{CH}$ \\
\hline 26 & 19.813 & 19.9 & 18.974 & 18.9 & $\mathrm{CH}_{3}$ \\
\hline 27 & 19.027 & 19.1 & 21.208 & 21.3 & $\mathrm{CH}_{3}$ \\
\hline 28 & 23.066 & 23.1 & 25.400 & 25.5 & $\mathrm{CH}_{2}$ \\
\hline 29 & 11.977 & 12.1 & 12.046 & 12.1 & $\mathrm{CH}_{3}$ \\
\hline
\end{tabular}

a Ouaternary $\left(4^{\circ}\right)$ Carbon

and permeability during development and stress conditions. $^{51,52}$ Literature suggests that $\beta$-sitosterol and stigmasterol are obtained in a mixture form, with stigmasterol having the maximum portion. ${ }^{53-55}$ The two compounds are both difficult to obtain in pure state since their structures are almost alike, only differing on the presence of carbon 22 and 23 sigma bond in $\beta$-sitosterol and double bond in stigmasterol. Moreover, only one fraction was spotted when the isolates were subjected to thin layer chromatography.

\section{CONCLUSION}

The present study proved that the extract of the aerial parts of $P$. odorata has significant antidiabetic activity. The bioassay-guided fractionation afforded white amorphous solid that was elucidated as a mixture of $\beta$-sitosterol and stigmasterol. Numerous studies have also demonstrated the hypoglycemic potentials of $\beta$-sitosterol and stigmasterol. Hence, the purified isolate can be potentially developed as therapeutic agents for glycemic control. 


\section{ACKNOWLEDGEMENT}

The authors wish to gratefully acknowledge Mapúa University for providing material support and adequate platform to execute this research. The Philippines' Bureau of Plant Industry is also acknowledged for the authentication of plant specimen. The plant materials were collected by Mapúa University alumni Clarisse Polintan.

\section{Author Contributions}

Conceptualization, R.A.M. and K.A.D.C.-C.; methodology, formal analysis and data curation, R.A.M., C.-C.S., P.-W.T. and K.A.D.C.-C.; writing-original draft preparation, R.A.M.; supervision, P.-W.T. and KA.D.C.-C. All authors read and approved the final manuscript.

\section{CONFLICT OF INTEREST}

The authors declare that there is no conflict of interests regarding the publication of this article.

\section{ABBREVIATIONS}

P. odorata: Premna odorata; WHO: World Health Organization; CIPGR: Crop Improvement and Plant Genetic Resources; NMR: Nuclear Magnetic Resonance; UV: Ultraviolet; PBS: Phosphate-Buffered Saline DCM: Dichloromethane; DE: Diethyl Ether; EtAc: Ethyl Acetate; DMSO: Dimethyl Sulfoxide; DNS: Dinitrosalicylic Acid; ANOVA: Analysis of Variance; SEM: Standard Error of Mean; PC: Positive Control.

\section{REFERENCES}

1. IDF Diabetes Atlas. Brussels: International Diabetes Federation. 2019. Available from: http://www.diabetesatlas.org/.

2. Watkins PJ. Cardiovascular disease, hypertension and lipids. Bmj. 2003;326(7394):874-6.

3. Hung HY, Qian K, Morris-Natschke SL, Hsu CS, Lee KH. Recent discovery of plant-derived anti-diabetic natural products. Natural Product Reports. 2012;29(5):580-606.

4. Moradi B, Abbaszadeh S, Shahsavari S, Alizadeh M, Beyranvand F. The most useful medicinal herbs to treat diabetes. Biomedical Research and Therapy. 2018;5(8):2538-51.

5. Osadebe PO, Odoh EU, Uzor PF. The search for new hypoglycemic agents from plants. African Journal of Pharmacy and Pharmacology. 2014;8(11):292303.

6. Rojas LB, Gomes MB. Metformin: An old but still the best treatment for type 2 diabetes. Diabetology and Metabolic Syndrome. 2013;5(1):1-5.

7. Clissold SP, Edwards C. Acarbose. Drugs. 1988;35(3):214-43.

8. Grant JS, Graven LJ. Progressing from metformin to sulfonylureas or meglitinides. Workplace Health and Safety. 2016;64(9):433-9.

9. Diamant $\mathrm{M}$, Heine RJ. Thiazolidinediones in type 2 diabetes mellitus. Drugs. 2003;63(13):1373-406.
10. Neumiller JJ, Wood L, Campbell RK. Dipeptidyl peptidase-4 inhibitors for the treatment of type 2 diabetes mellitus. Pharmacotherapy: The Journal of Human Pharmacology and Drug Therapy. 2010;30(5):463-84.

11. Vivian EM. Sodium-glucose co-transporter 2 (SGLT2) inhibitors: a growing class of antidiabetic agents. Drugs in Context. 2014;3:1-19.

12. Marín-Peñalver JJ, Martín-Timón I, Sevillano-Collantes C, Cañizo-Gómez DFJ. Update on the treatment of type 2 diabetes mellitus. World Journal of Diabetes. 2016;7(17):354-95.

13. Alarcon-Aguilara FJ, Roman-Ramos R, Perez-Gutierrez S, Aguilar-Contreras A, Contreras-Weber CC, Flores-Saenz JL. Study of the anti-hyperglycemic effect of plants used as antidiabetics. Journal of Ethnopharmacology. 1998;61(2):101-10.

14. Welihinda J, Karunanayake EH, Sheriff MH, Jayasinghe KS. Effect of Momordica charantia on the glucose tolerance in maturity onset diabetes. Journal of Ethnopharmacology. 1986;17(3):277-82.

15. Sukandar EY, Permana H, Adnyana IK, Sigit JI, llyas RA, Hasimun P, et al. Clinical study of turmeric (Curcuma longa L.) and garlic (Allium sativum L.) extracts as antihyperglycemic and antihyperlipidemic agent in type-2 diabetes-dyslipidemia patients. IJP-International Journal of Pharmacology. 2010;6(4):456-63.

16. Sokeng SD, Rokeya B, Hannan JM, Junaida K, Zitech P, Ali L, et al. Inhibitory effect of Ipomoea aquatica extracts on glucose absorption using a perfused rat intestinal preparation. Fitoterapia. 2007;78(7-8):526-9.

17. Anthanont $P$, Lumlerdkij N, Akarasereenont $P$, Vannasaeng $S$, Sriwijitkamol A. Moringa oleifera leaf increases insulin secretion after single dose administration: A preliminary study in healthy subjects. Journal of the Medical Association of Thailand. 2016;99(3):308-13.

18. Kakuda T, Sakane I, Takihara T, Ozaki Y, Takeuchi H, Kuroyanagi M. Hypoglycemic effect of extracts from Lagerstroemia speciosa L. leaves in genetic diabetic KK-AY mice. Bioscience, Biotechnology and Biochemistry. 1996;60(2):204-8.

19. Choudhury H, Pandey M, Hua CK, Mun CS, Jing JK, Kong L, et al. An update on natural compounds in the remedy of diabetes mellitus: A systematic review. Journal of Traditional and Complementary Medicine. 2018;8(3):361-76.

20. Asmat $U, A$ bad $K$, Ismail $K$. Diabetes mellitus and oxidative stress: A concise review. Saudi Pharmaceutical Journal. 2016;24(5):547-53.

21. Oh YS. Plant-derived compounds targeting pancreatic beta cells for the treatment of diabetes. Evidence-Based Complementary and Alternative Medicine. 2015;2015:629863.

22. Kooti W, Farokhipour M, Asadzadeh Z, Ashtary-Larky D, Asadi-Samani M. The role of medicinal plants in the treatment of diabetes: A systematic review. Electronic Physician. 2016;8(1):1832-42.

23. Fowler MW. Plants, medicines and man. Journal of the Science of Food and Agriculture. 2006;86(12):1797-804.

24. Munir AA. A taxonomic revision of the genus Premna L.(Verbenaceae) in Australia. Journal of the Adelaide Botanic Garden. 1984;1-43.

25. Dianita R, Jantan I. Ethnomedicinal uses, phytochemistry and pharmacological aspects of the genus Premna: A review. Pharmaceutical Biology. 2017;55(1):1715-39.

26. Quisumbing E. Medicinal Plants of the Philippines. Katha Publishing Co. Inc. 1978;800-1.

27. Tan ML. Philippine medicinal plants in common use: Their phytochemistry and pharmacology, Quezon City: Alay Kapwa Kilusang Pangkalusugan. 1980;41:72.

28. Ong CY, Ling SK, Ali RM, Chee CF, Samah ZA, Ho AS, et al. Systematic analysis of in vitro photo-cytotoxic activity in extracts from terrestrial plants in Peninsula Malaysia for photodynamic therapy. Journal of Photochemistry and Photobiology B: Biology. 2009;96(3):216-22.

29. Elmaidomy $\mathrm{AH}$, Mohammed R, Hassan $\mathrm{MH}$, Owis IA, Rateb EM, Khanfar $\mathrm{AM}$, et al. Metabolomic profiling and cytotoxic tetrahydrofurofuran lignans investigations from Premna odorata Blanco. Metabolites. 2019;9(10):223.

30. Ali AM, Mackeen MM, Saleh $\mathrm{H}$, Junainah AE, Hamidi IN, Faujan $\mathrm{H}$, et al. Antiviral and cytotoxic activities of some plants used in Malaysian indigenous medicine. Pertanika Journal of Tropical Agricultural Science. 1996;19(2/3):129-36. 
31. Pinzon LC, Uy MM, Sze KH, Wang M, Chu IK. Isolation and characterization of antimicrobial, anti-inflammatory and chemopreventive flavones from Premna odorata Blanco. Journal of Medicinal Plants Research. 2011;5(13):2729-35.

32. Kazeem MI, Adamson JO, Ogunwande IA. Modes of inhibition of $\alpha$-amylase and $\alpha$-glucosidase by aqueous extract of Morinda lucida Benth leaf. Bio Med Research International. 2013;2013:527570.

33. Bachhawat JA, Shihabudeen MS, Thirumurugan K. Screening of fifteen Indian ayurvedic plants for alpha-glucosidase inhibitory activity and enzyme kinetics. International Journal of Pharmacy and Pharmaceutical Sciences. 2011;3(4):267-74.

34. Cirillo VP. Mechanism of glucose transport across the yeast cell membrane. Journal of Bacteriology. 1962;84(3):485-91.

35. Whitby GS. Some new reactions for the detection of sterols. Research and reviews: journal of medical and health sciences. 1923;17(1):5-12.

36. Agarwal P, Gupta R. Alpha-amylase inhibition can treat diabetes mellitus. Res Rev J Med Health Sci. 2016;5(4):474-6.

37. Kalra S. Alpha glucosidase inhibitors. JPMA. The Journal of the Pakistan Medical Association. 2014;64(4):474.

38. Wiernsperger NF. Is non-insulin dependent glucose uptake a therapeutic alternative? Part 1: physiology, mechanisms and role of non-insulindependent glucose uptake in type 2 diabetes. Diabetes and Metabolism. 2005;31(5):415-26.

39. Elmaidomy AH, Hassan HM, Amin E, Mohamed WA, Hetta MH. Chemical Composition and in vivo Anti-inflammatory Activity of the Lipid Extract from Premna odorata Blanco cultivated in Egypt. World Journal of Pharmacy and Pharmaceutical Sciences. 2015;5:129-35.

40. Lirio SB, Macabeo AP, Paragas EM, Knorn M, Kohls P, Franzblau SG, et al. Antitubercular constituents from Premna odorata Blanco. Journal of Ethnopharmacology. 2014;154(2):471-4

41. Cayme JM, Ragasa CY. Structure elucidation of $\beta$-stigmasterol and $\beta$-sitosterol from Sesbania grandifora [Linn.] Pers. and $\beta$-carotene from Heliotropium indicum Linn. by NMR spectroscopy. Kimika. 2004;20:5-12.

42. Soekamto $\mathrm{NH}$, Ahmad F, Appa FE. Potential of stigmasterol from EtOAc extract Melochia umbellata (Houtt) Stapf var. Visenia as Dengue Antivirus. In Journal of Physics: Conference Series. IOP Publishing. J. Phys. 2019;1341:032044.
43. Alam MS, Chopra N, Ali M, Niwa M. Oleanen and stigmasterol derivatives from Ambroma augusta. Phytochemistry. 1996;41(4):1197-200.

44. Mahato SB, Kundu AP. ${ }^{13} \mathrm{C}$ NMR spectra of pentacyclic triterpenoids-a compilation and some salient features. Phytochemistry. 1994;37(6):1517-75.

45. Kumar S, Kumar V, Prakash O, Ali M. Enzymes inhibition and antidiabetic effect of isolated constituents from Callistemon lanceoalatus. The Natural Products Journal. 2013;3(4):252-9.

46. Gupta R, Sharma AK, Dobhal MP, Sharma MC, Gupta RS. Antidiabetic and antioxidant potential of $\beta$-sitosterol in streptozotocin-induced experimental hyperglycemia. Journal of Diabetes. 2011;3(1):29-37.

47. Radika MK, Viswanathan P, Anuradha CV. Nitric oxide mediates the insulin sensitizing effects of $\beta$-sitosterol in high fat diet-fed rats. Nitric Oxide. 2013;32:43-53.

48. Jamaluddin F, Mohamed S, Lajis MN. Hypoglycaemic effect of Parkia speciosa seeds due to the synergistic action of $\beta$-sitosterol and stigmasterol. Food Chemistry. 1994;49(4):339-45

49. Wang J, Huang M, Yang J, Ma X, Zheng S, Deng S, et al. Anti-diabetic activity of stigmasterol from soybean oil by targeting the GLUT4 glucose transporter. Food and Nutrition Research. 2017;61(1):1364117.

50. Trautwein EA, Demonty I. Phytosterols: natural compounds with established and emerging health benefits. Oléagineux, Corps Gras, Lipides. 2007;14(5):259-66.

51. Grunwald C. Effects of free sterols, steryl ester and steryl glycoside on membrane permeability. Plant Physiology. 1971;48(5):653.

52. Hartmann MA. Plant sterols and the membrane environment. Trends in Plant Science. 1998;3(5):170-5.

53. Kamboj A, Saluja AK. Isolation of stigmasterol and $\beta$-sitosterol from petroleum ether extract of aerial parts of Ageratum conyzoides (Asteraceae). Int J Pharm Pharm Sci. 2011;3(1):94-6.

54. Pateh UU, Haruna AK, Garba M, Iliya I, Sule IM, Abubakar MS, et al. Isolation of stigmasterol, $\beta$-sitosterol and 2-hydroxyhexadecanoic acid methyl ester from the rhizomes of Stylochiton lancifolius Pyer and Kotchy (Araceae). Nigerian Journal of Pharmaceutical Sciences. 2009;8(1):19-25.

55. Pierre LL, Moses MN. Isolation and characterisation of stigmasterol and $\beta$-sitosterol from Odontonema strictum (acanthaceae). Journal of Innovations in Pharmaceuticals and Biological Sciences. 2015;2(1):88-95.

\section{PICTORIAL ABSTRACT}

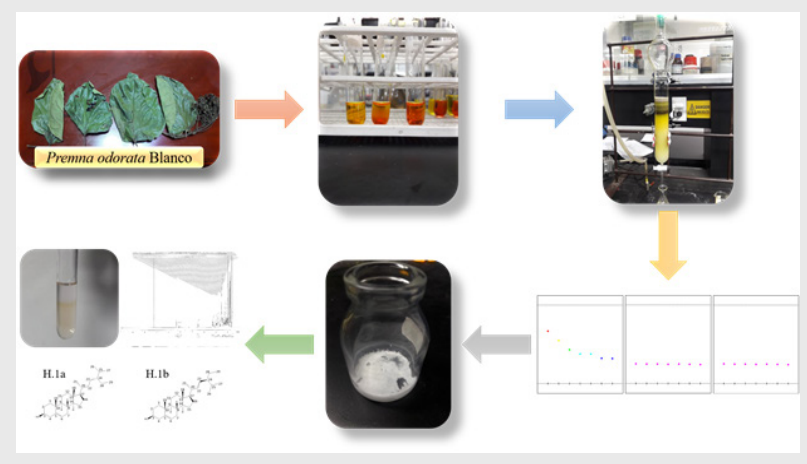

\section{SUMMARY}

The isolated compounds, $\beta$-sitosterol and stigmasterol, from the aerial parts of Premna odorata Blanco exhibited significant antidiabetic activity and may be potentially developed as a novel adjuvant treatment for type 2 diabetes.

\section{About Authors}

Ronel Abad Mendoza is a dual-degree holder of Bachelor of Science in Chemical Engineering and Chemistry from Mapúa University, Manila, Philippines. The author's area of interest includes Natural Products and Pharmacology.

Chien-Chang Shen, Ph.D., Associate Research Fellow in Division of Chinese Medicinal Chemistry, National Research Institute of Chinese Medicine, Ministry of Health and Welfare, Taiwan, ROC. His areas of interest are Natural Product chemistry and Synthetic Organic Chemistry. 
Po-Wei Tsai is working as an Associate Professor in the Department of Medical Sciences Industry, College of Health Sciences, Chang Jung Christian University, Tainan, Taiwan. Author's area of interest is research activities in Phytochemistry, Antioxidant, Anti-osteoarthritis in Natural Products.

Kathlia Aguila De Castro-Cruz is a full-time Professor in the School of Chemical, Biological, and Materials Engineering, and Sciences, Mapúa University, Manila, Philippines. The author is highly interested in research activities related to organic total synthesis, isolation and structural elucidation of Natural Products.

Cite this article: Mendoza RA, Shen CC, Tsai PW, De Castro-Cruz KA. Bioassay-Guided Isolation and Structure Elucidation of Bioactive Phytoconstituents with Inhibitory Activity against Carbohydrate-Hydrolyzing Enzymes from the Aerial Parts of Premna odorata Blanco. Indian J of Pharmaceutical Education and Research. $2021 ; 55(3): 846-56$. 